\title{
Pelatihan Media Pembelajaran Dengan Ms. Office Power Point Bagi Guru SMA IT Plus Bazma Brilliant Dumai
}

\author{
Erna Alimudin $^{1 *}$, Tri Yuliati ${ }^{2}$, Nur Budi Nugraha ${ }^{3}$ \\ ${ }^{1}$ Program Studi Teknik Elektronika, Politeknik Negeri Cilacap, Indonesia \\ ${ }^{2,3}$ Program Studi Informatika, Sekolah Tinggi Teknologi Dumai, Indonesia \\ Email: ${ }^{1}$ ernaalimudin@gmail.com, ${ }^{2}$ triyuliati00@gmail.com, ${ }^{3}$ nurbudinugroho87@gmail.com
}

\section{INFORMASI ARTIKEL}

\section{Data artikel:}

Naskah masuk, 31 Juli 2019

Direvisi, 27 Agustus 2019

Diterima, 30 Agustus 2019

\section{Kata Kunci:}

Guru SMA

Media Pembelajaran

Pelatihan

\begin{abstract}
ABSTRAK
Abstract- Teachers are currently required to use learning media, in accordance with government regulations. Learning media are used for teaching materials for student learning. Learning evaluation can consist of questions or quizzes using multiple choice quiz. Evaluation of student learning by using learning media is one of the things which teachers of IT PLUS BAZMA Briliant High School. Therefore, STT Dumai held community service for IT PLUS BAZMA Brilliant High School Teachers, namely, Training to Make Multiple Choice Test Using Ms. Office Power Point for IT Plus Bazma Brilliant High School Teachers on Wednesday, January 30, 2018. Training provided for three materials, namely techniques and things to consider in making Power Point, the use of features in Power Point, and make a quiz with Power Point. The training was attended by 19 teachers and held for approximately 2 hours. The training begins with the implementing material ending with practice. The material given by sequence is in accordance with the desired goals, namely making learning material and also student learning.
\end{abstract}
Abstrak- Guru saat ini diminta untuk menggunakan media pembelajaran, sesuai dengan peraturan pemerintah. Media pembelajaran digunakan untuk bahan ajar untuk pembelajaran siswa. Evaluasi pembelajaran dapat terdiri dari pertanyaan atau kuis menggunakan kuis pilihan ganda. Evaluasi pembelajaran siswa dengan menggunakan media pembelajaran adalah salah satu hal yang dilakukan guru-guru SMA IT PLUS BAZMA Briliant. Oleh karena itu, STT Dumai mengadakan pengabdian kepada guru-guru SMA Brilliant IT PLUS BAZMA, yaitu, Pelatihan untuk Membuat Tes Pilihan Ganda dengan menggunakan Ms. Power Point Office untuk IT Plus Bazma Brilliant High Teacher Teachers pada hari Rabu, 30 Januari 2018. Pelatihan diberikan untuk tiga bahan, yaitu teknik dan hal-hal yang perlu dipertimbangkan dalam membuat Power Point, penggunaan fitur di Power Point, dan membuat kuis dengan Power Point. Pelatihan dihadiri oleh 19 guru dan diadakan selama kurang lebih 2 jam. Pelatihan dimulai dengan materi implementasi yang diakhiri dengan latihan. Materi yang 
diberikan secara berurutan sesuai dengan tujuan yang diinginkan, yaitu membuat materi pembelajaran dan juga belajar siswa.

\section{Korespondensi:}

\section{Erna Alimudin}

Program Studi Teknik Elektronika, Politeknik Negeri Cilacap

J1. Dr. Soetomo No.1 Karangcengis, Sidakarya Cilacap, Indonesia

\section{PENDAHULUAN}

Guru adalah pendidik profesional dengan tugas utama mendidik, mengajar, membimbing, mengarahkan, melatih, menilai, dan mengevaluasi peserta didik pada pendidikan anak usia dini jalur pendidikan formal, pendidikan dasar, dan pendidikan menengah. Dalam melaksanakan tugas utamanya tersebut guru tentu memerlukan media pembelajaran. Media pembelajaran merupakan salah satu kunci suksesnya penyampaian materi kepada siswa-siswa yang diajarkan. (Nurseto, 2011) Materi yang disampaikan melalui media pembelajaran tentunya akan lebih menarik, interaktif, serta mudah dipahami. (Ainin, Ahsanuddin, \& Asrori, 2018) Selain itu, melalui media pembelajaran, guru dapat memberikan materi dengan lebih mudah dibandingkan dengan metode ceramah. (Kurnia \& Nugroho, 2017)

Peraturan Pemerintah Nomor 74 Tahun 2008 Tentang Guru, Bagian I: Kompetensi, Pasal 3, menyatakan bahwa Guru harus memiliki standar kompetensi pedagogik, antara lain pemahaman wawasan atau landasan kependidikan, pemahaman terhadap peserta didik, pengembangan kurikulum atau silabus, perancangan pembelajaran, pelaksanaan pembelajaran yang mendidik dan dialogis. pemanfaatan teknologi pembelajaran, evaluasi hasil belajar, dan pengembangan peserta didik untuk mengaktualisasikan berbagai potensi yang dimilikinya.

Melalui peraturan tersebut, guru diwajibkan untuk mampu melaksanakan pembelajaran yang mendidik dan dialogis. Proses pembelajaran yang mendidik dan dialogis tentu dapat terlaksana dengan baik dengan memanfaatkan teknologi sebagai media pembelajaran, seperti yang tertuang dalam
Pasal 3, No. 6. (Departemen Pendidikan Nasional, 2009)

Masalah yang timbul kemudian adalah ketika guru tidak mampu memanfaatkan teknologi sebagai media pembelajaran sehingga pengajaran hanya disampaikan melalui metode speech saja. Hal ini tentu akan berdampak pada kejenuhan siswa, menurunkan minat belajar, serta menambah kesulitan pemahaman terhadap materi yang diajarkan. (Fuad et al., 2017)

Materi siswa Sekolah Menengah Atas (SMA) dirancang untuk bisa melatih skill siswa sehingga lebih cakap dalam berbagai bidang ketika lulus nantinya. (Ayuningtyas, H., Pujiastuti, Retnowati, \& Indrianingsih, 2018) Materinya tentu tidak hanya teori tapi disertai praktik. Dalam proses belajar-mengajar teori dan praktik ini tentunya guru akan lebih mudah jika menggunakan media pembelajaran yang menarik. (Nurseto, 2011)

\section{METODE PELAKSANAAN}

Peraturan Menteri Pendidikan Nasional Republik Indonesia No. 41 Tahun 2007 tertuang bahwa dalam kegiatan eksplorasi pembelajaran guru menggunakan media pembelajaran. (Badan Standar Nasional Pendidikan, 2007) dalam Bab III Perencanaan Pembelajaran Peraturan Menteri Pendidikan dan Kebudayaan Nomor 22 Tahun 2016 tertuang bahwa setiap pendidik pada satuan pendidikan berkewajiban menyusun RPP secara lengkap dan sistematis agar pembelajaran berlangsung secara interaktif, inspiratif, menyenangkan, menantang, efisien, memotivasi peserta didik untuk berpartisipasi aktif, serta memberikan ruang yang cukup bagi prakarsa, kreativitas, dan kemandirian sesuai dengan bakat, minat, dan perkembangan fisik serta psikologis peserta didik. Oleh karena itu, 
guru memang dituntut untuk menggunakan media pembelajaran yang interaktif.

Pada suatu kesempatan kunjungan STT Dumai ke SMA IT PLUS BAZMA Brilliant, pihak STT Dumai berdiskusi dengan Kepala Sekolah SMA IT PLUS BAZMA Brilliant dan beberapa tenaga pengajar. Pada kesempatan tersebut tenaga pengajar SMA IT PLUS BAZMA Brilliant mengemukakan bahwa mereka kesulitan dalam membuat media pembelajaran yang menarik. Karena materi yang diajarkan ke siswa adalah teori dan praktik, maka tidak mungkin hanya diajarkan melalui metode speech. Media pembelajaran yang paling banyak digunakan adalah Microsoft (Ms.) Power Point. Namun, dalam membuat materi pelajaran dengan Ms. Power Point guru-guru SMA IT PLUS BAZMA Brilliant kerap mengalami kesulitan dalam membuat atau menentukan template, memilih isi materi yang penting, serta membuat tampilan yang menarik secara keseluruhan. Hal ini kemudian mendorong pihak STT Dumai untuk memberikan pelatihan untuk menambah pengetahuan guru-guru SMA IT PLUS BAZMA Brilliant untuk merancang media pembelajaran yang interaktif dengan $M s$. Power Point.

Kegiatan pengabdian ini telah dilaksanakan 30 Januari 2018 di SMA IT PLUS BAZMA Brilliant Bukit Datuk, Kec. Dumai Selatan, Dumai. Kegiatan ini diisi dengan pelatihan pembuatan media pembelajaran power point untuk guru-guru SMA IT PLUS BAZMA Brilliant. Pelatihan ini meliputi materi yaitu teknikteknik dan hal-hal yang perlu diperhatikan dalam pembuatan Power Point, pemanfaatan fitur-fitur di Power Point, serta membuat kuis dengan Power Point. Kegiatan ini diikuti oleh 19 orang guru. Kegiatan dibuka dengan sambutan hangat dari Kepala Sekolah SMA IT PLUS BAZMA Brilliant. Kegiatan selanjutnya adalah pemberian materi serta praktek. Time table pengabdian kepada masyarakat pada kegiatan ini dapat dilihat pada tabel 1 .
Tabel 1. Timeline kegiatan pengabdian kepada masyarakat

\begin{tabular}{|c|c|c|}
\hline \multicolumn{3}{|c|}{ Persiapan } \\
\hline Langkah & Tujuan & Hasil \\
\hline $\begin{array}{l}\text { Pembentukan } \\
\text { panitia } \\
\text { kegiatan }\end{array}$ & $\begin{array}{l}\text { Membuat } \\
\text { struktur } \\
\text { kepanitian } \\
\text { dan } \\
\text { pembagian } \\
\text { tugas }\end{array}$ & $\begin{array}{l}\text { Struktur } \\
\text { kepanitian } \\
\text { terdiri dari } \\
\text { tim dosen } \\
\text { STT Dumai }\end{array}$ \\
\hline $\begin{array}{l}\text { Administrasi } \\
\text { kegiatan }\end{array}$ & $\begin{array}{l}\text { Mengelola } \\
\text { kegiatan dan } \\
\text { bukti } \\
\text { pelaksanaan } \\
\text { pengabdian }\end{array}$ & $\begin{array}{l}\text { Daftar hadir } \\
\text { peserta dan } \\
\text { tim dosen, } \\
\text { berita acara } \\
\text { pelaksanaan }\end{array}$ \\
\hline $\begin{array}{l}\text { Pembuatan } \\
\text { modul dan } \\
\text { banner } \\
\text { pelatihan }\end{array}$ & $\begin{array}{l}\text { Membuat } \\
\text { modul dan } \\
\text { banner } \\
\text { untuk } \\
\text { peserta dan } \\
\text { sebagai } \\
\text { bahan } \\
\text { presentasi }\end{array}$ & $\begin{array}{l}\text { Materi } \\
\text { pelatihan: } \\
\text { 1. Desain } \\
\text { presentasi } \\
\text { 2. Latihan } \\
\text { membuat } \\
\text { presentasi } \\
\text { materi ajar } \\
\text { 3. Latihan } \\
\text { membuat } \\
\text { soal } \\
\end{array}$ \\
\hline \multicolumn{3}{|c|}{ Pelaksanaan } \\
\hline Langkah & Tujuan & Hasil \\
\hline $\begin{array}{l}\text { Pelaksanaan } \\
\text { Pelatihan }\end{array}$ & $\begin{array}{l}\text { Pelaksanaan } \\
\text { pelatihan }\end{array}$ & $\begin{array}{l}\text { Pelaksanaan } \\
\text { pelatihan }\end{array}$ \\
\hline \multicolumn{3}{|c|}{ Penutup } \\
\hline Langkah & Tujuan & Hasil \\
\hline $\begin{array}{l}\text { Evaluasi } \\
\text { kegiatan }\end{array}$ & $\begin{array}{l}\text { Mengetahui } \\
\text { hal-hal } \\
\text { yang } \\
\text { dianggap } \\
\text { perlu } \\
\text { untuk } \\
\text { perbaikan } \\
\text { kedepannya }\end{array}$ & $\begin{array}{l}\text { Saran untuk } \\
\text { perbaikan } \\
\text { kegiatan } \\
\text { pengabdian } \\
\text { selanjutnya }\end{array}$ \\
\hline $\begin{array}{l}\text { Laporan } \\
\text { kegiatan }\end{array}$ & $\begin{array}{l}\text { Melaporkan } \\
\text { serangkaian } \\
\text { kegiatan } \\
\text { pengabdian }\end{array}$ & $\begin{array}{l}\text { Laporan } \\
\text { kegiatan } \\
\text { PPM }\end{array}$ \\
\hline
\end{tabular}




\section{HASIL DAN PEMBAHASAN}

\subsection{Pemberian Materi Kegiatan}

Pelaksanaan kegiatan pelatihan dilakukan oleh para guru dan mengikuti materinya dengan tertib. Materi diberikan dalam tiga sesi, yang pertama materi tentang teknik-teknik desain presentasi, kemudian praktek membuat presentasi materi ajar, dan terakhir praktek membuat soal.

Sesi pertama yaitu materi yang diberikan dengan metode speech dari Dosen STT Dumai. Materi yang diberikan mengenai teknik-teknik desain presentasi yang menarik. Langkahlangkahnya, yaitu:

1) Menggunakan slide pembuka presentasi yang WAH, seperti pada Gambar 1.

2) Gunakan skema warna yang menarik

3) Gunakan lebih banyak, icon, symbol, gambar, atau animasi dan sedikit tulisan.

4) Pastikan teks digunakan dengan tepat dan mudah dibaca

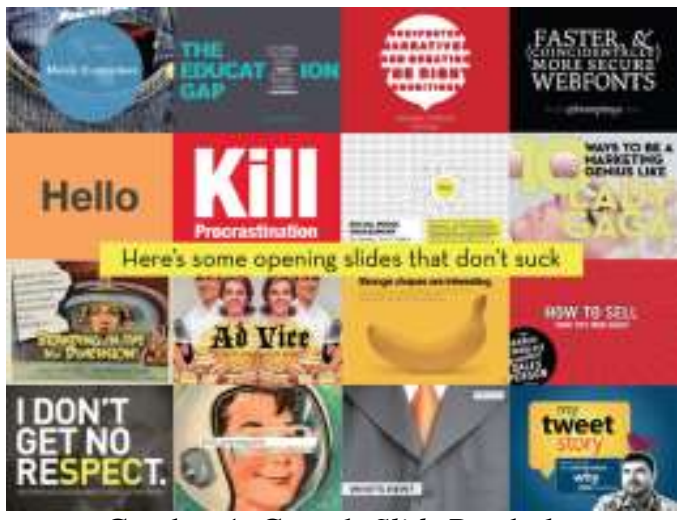

Gambar 1. Contoh Slide Pembuka

CONTRAST EXAMPLES

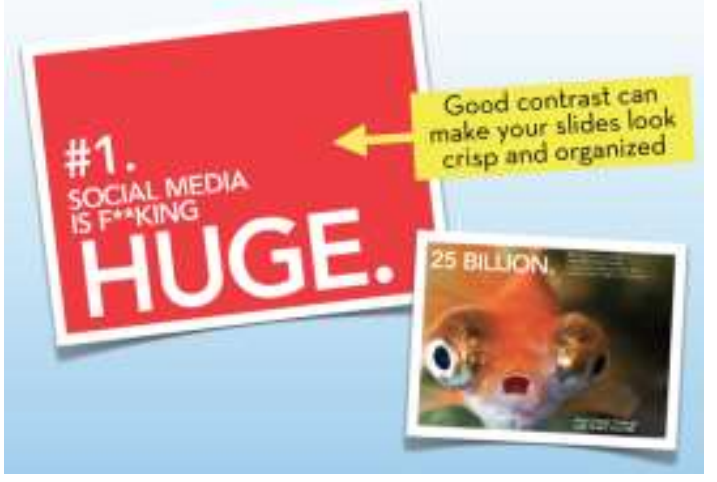

Gambar 2. Contoh Kontras pada Presentasi

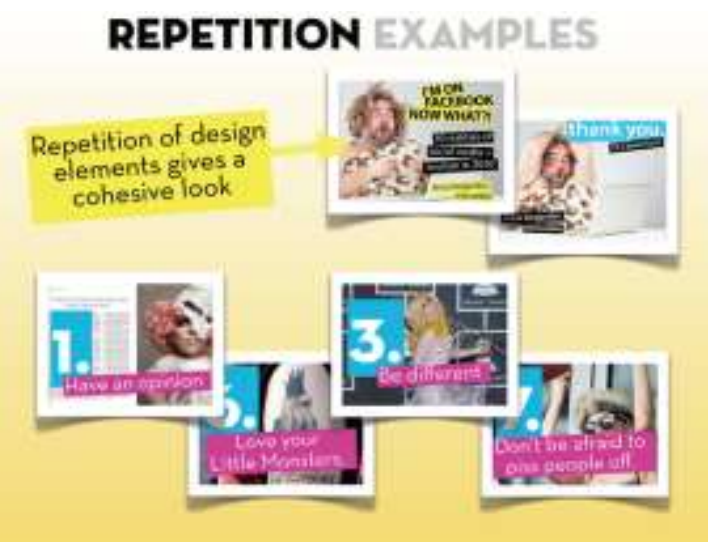

Gambar 3. Contoh Pengulangan pada Presentasi

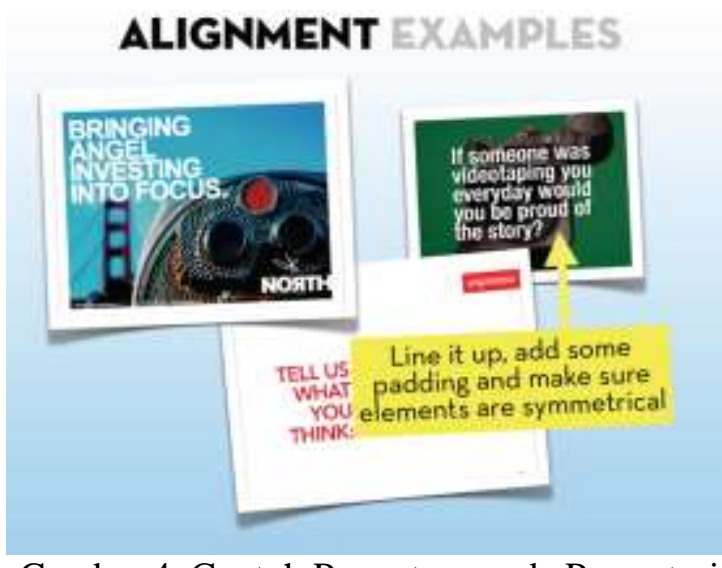

Gambar 4. Contoh Pererataan pada Presentasi

\section{PROXIMITY EXAMPLES}

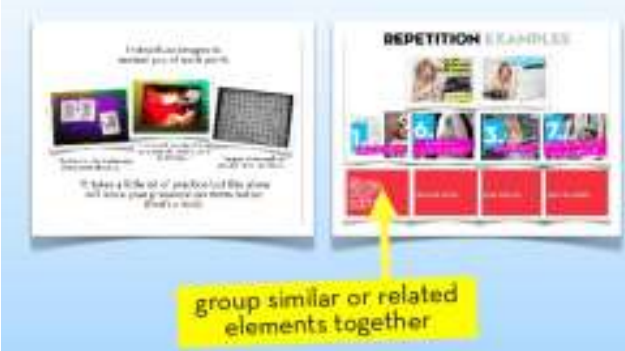

Gambar 5. Contoh Keterkaitan pada Presentasi

Selain itu dijelaskan juga poin-poin penting yang perlu diperhatikan dalam pembuatan presentasi, yaitu antara lain:

1) Kontras

Ciptakan perbedaan antara elemen-elemen dalam slide. Kontras berfungsi untuk menciptakan perbedaan, perbandingan, dan membuat sesuatu jadi lebih menarik. Kontras dapat dibuat dengan memberikan ukuran berbeda, warna berbeda, atau tampilan yang berbeda. Contoh materi seperti pada Gambar 2 . 


\section{2) Pengulangan}

Pada meteri ini seperti pada Gambar 3, disampaikan bahwa manfaatkan elemen yang bisa diulang dalam presentasi antara satu slide dengan slide yang lain. Ulang warna, pola, tata letak dan banyak hal lainnya. Pengulangan menciptakan harmoni dalam keseluruhan slide presentasi.

\section{3) Perataan}

Pada Gambar 4 disampaikan bahwa tidak ada elemen dalam slide presentasi berupa gambar atau teks yang diletakkan secara sembarangan. Semuanya diletakkan dengan maksud tertentu. Gunakan perataan yang konsisten untuk menjadikan slide tampil indah sekaligus profesional.

\section{4) Keterkaitan}

Elemen terkait harus dikelompokkan bersama, seperti disampaikan pada Gambar 5.

\subsection{Pelaksanaan Kegiatan}

Pelaksanaan Kegiatan dimulai dengan pembukaan oleh pihak STT Dumai dan diisi dengan sambutan dari Kepala Sekolah SMA IT Plus BAZMA Brilliant Dumai seperti pada Gambar 6. Selanjutnya, kegiatan pemberian materi yang disampaikan oleh Dosen STT Dumai seperti pada Gambar 7.

Setelah penyampaian materi, dilakukan praktek oleh guru-guru SMA IT Plus BAZMA Brilliant. Pelaksanaan praktek seperti pada Gambar 8 dan 9.

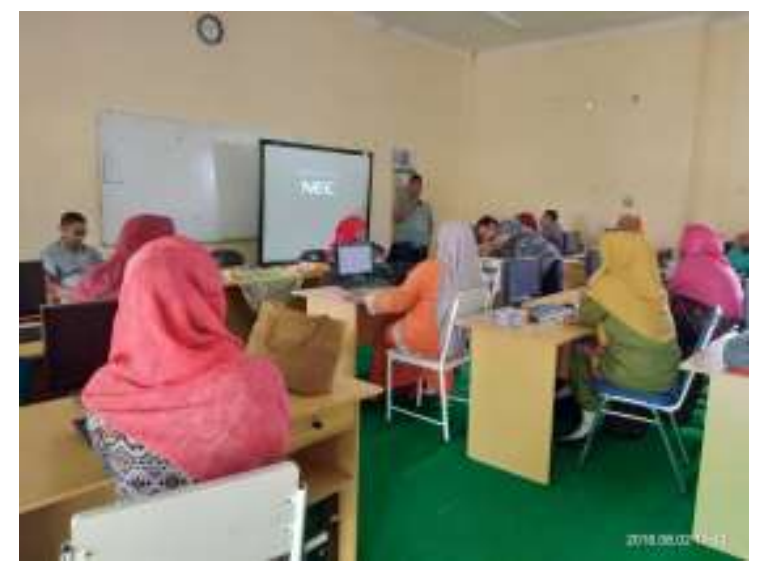

Gambar 6. Suasana Pembukaan Acara

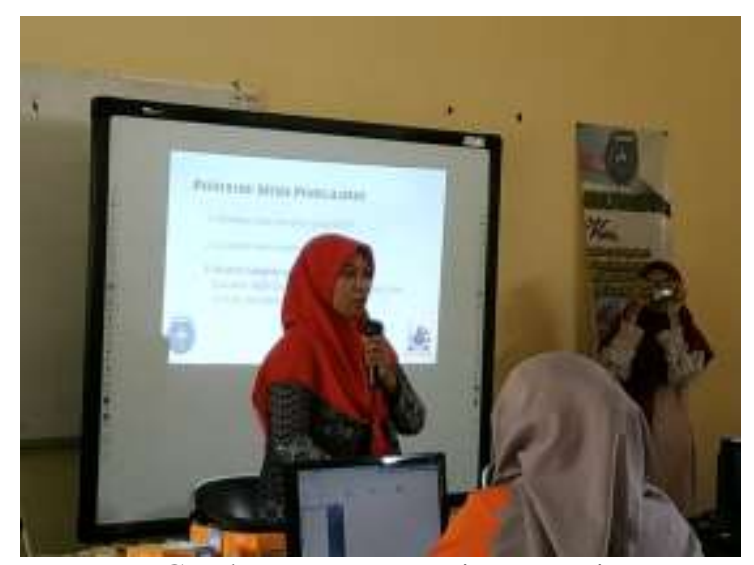

Gambar 7. Penyampaian Materi

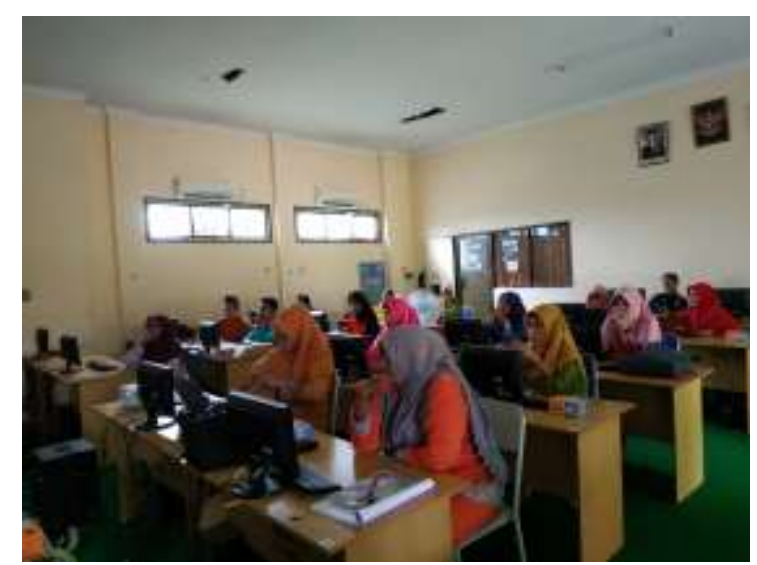

Gambar 8. Pelaksanaan Praktek

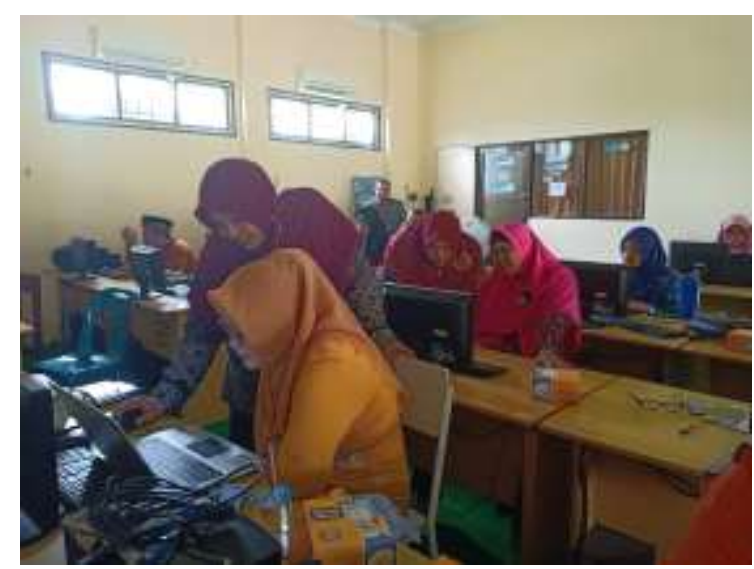

Gambar 9. Pendampingan Praktek oleh Dosen STT Dumai

Antusias para guru dalam melakukan praktek juga terlihat saat pelatihan berjalan para guru kerap bertanya untuk meminta pendampingan langsung dari tim pengabdian masyarakat yang hadir. Hasil praktek guruguru juga cukup baik. Seluruh guru yang hadir 
mencoba praktek langsung dan mengikuti dengan seksama sampai praktek berakhir. Suasana penutupan acara dapat dilihat pada Gambar 10 dan Gambar 11.

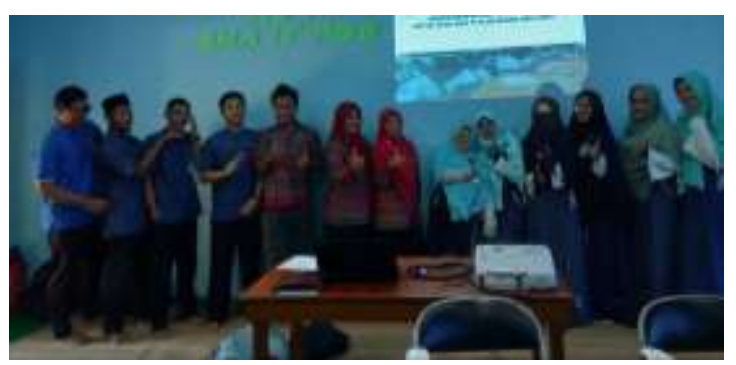

Gambar 10. Suasana Penutupan Acara

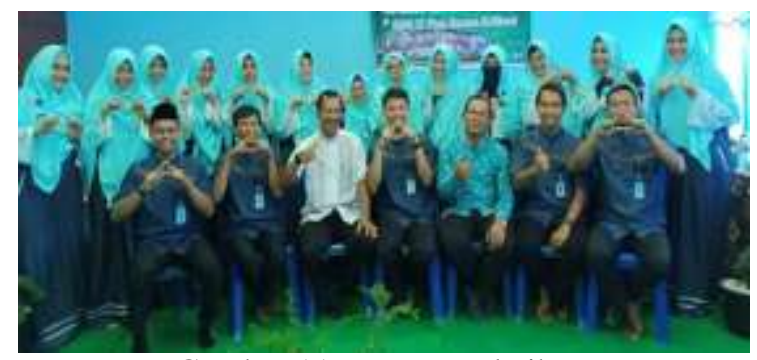

Gambar 11. Peserta Pelatihan

\section{KESIMPULAN}

Pelatihan Membuat Media Pembelajaran Menggunakan Ms. Office Power Point Bagi Guru SMA IT Plus Bazma Brilliant pada hari Rabu tanggal 30 Januari 2018 telah dilaksanakan dengan tertib dan lancar. Kegiatan pelatihan dibagi dalam tiga materi dan dua sesi. Materinya antara lain teknikteknik dan hal-hal yang diperlukan untuk membuat presentasi media pembelajaran, membuat materi ajar dengan Power Point, serta membuat kuis dengan Power Point. Sesi pelatihan dibagi menjadi dua, yaitu pemberian materi serta pemberian materi disertai praktek langsung. Guru-guru SMA IT PLUS BAZMA Brilliant terlihat begitu antusias dan aktif mengikuti kegiatan. Hasil praktek juga terlihat menunjukkan Semangat tersebut datang dari keingintahuan yang besar serta keinginna untuk mampu memenuhi kewajiban peraturan pemerintah untuk guru yaitu pemanfaatan media pembelajaran.

Kegiatan pengabdian masyarakat dengan bentuk pelatihan untuk guru-guru masih perlu dilakukan di sekolah-sekolah lain. Karena berdasarkan pengamatan ketika melaksanakan pengabdian, terlihat bahwa guru-guru memang masih sangat minim pengetahuan dalam menggunakan power point. Sementara guru-guru diwajibkan untuk menggunakan media pembelajaran. Kegiatankegiatan seperti ini tentu membantu guruguru untuk mampu memenuhi kewajiban tersebut.

\section{UCAPAN TERIMA KASIH}

Pihak Sekolah Tinggi Teknologi Dumai mengucapkan terimakasih kepada Pihak SMA IT Plus Bazma Brilliant yang telah bersedia memberikan waktu dan kesempatan untuk mengadakan pelatihan.

\section{DAFTAR PUSTAKA}

Ainin, M., Ahsanuddin, M., \& Asrori, I. (2018). Pelatihan Powerpoint Bagi Guru Bahasa Arab MTs Kota dan Kabupaten Kediri, 1(1), 74-79.

Ayuningtyas, A., H., A. S., Pujiastuti, A., Retnowati, N. D., \& Indrianingsih, Y. (2018). Pendampingan Pembuatan Bahan Ajar Bagi Guru Sekolah Dasar Islam Terpadu ( SDIT ) Salsabila Al Muthi' in Berbasis Multimedia dengan Menggunakan Microsoft Power Point. Jurnal Pengabdian Masyarakat Bidang Teknologi, 1(No. 1), 1-6.

Badan Standar Nasional Pendidikan. (2007). Peraturan Menteri Pendidikan Nasional Republik Indonesia Nomor 41 Tahun 2007.

Departemen Pendidikan Nasional. (2009). Peraturan Pemerintah Nomor 74 Tahun 2008 Tentang Guru.

Fuad, E., Mukhtar, H., Unik, M., Amien, J. Al, Studi, P., \& Informatika, T. (2017). Pelatihan Pembuatan Media Pembelajaran Interaktif Bagi Para Guru SMK Negeri 3. JURNAL Untuk $M u$ NegeRI, l(1).

Kurnia, E. D., \& Nugroho, Y. E. (2017). Pelatihan Pembuatan Media Pembelajaran Aksara Jawa Bagi Guru Bahasa Jawa SMA DI Kabupaten, 2(2), 101-112.

Nurseto, T. (2011). Membuat Media Pembelajaran yang Menarik. Jurnal Ekonomi Dan Pendidikan, 8, 19-35. 